\title{
Analisis Potensi Cemaran Sisa Penggunaan Antibiotik di Perairan Umum (Studi Kasus : Badan Sungai Musi Kota Palembang)
}

\author{
Ian Kurniawan ${ }^{1}$, Pra Dian Mariadi ${ }^{2 *}$ \\ *e-mail: pradian@ukmc.ac.id \\ 1,2 Program Studi Diploma IV Teknologi Laboratorium Medik \\ Universitas Katolik Musi Charitas
}

\begin{abstract}
The Antibiotics is the basic needs of human health serves to inhibit or kill the growth of microorganisms. Sources of activities had potential to produce antibiotic in water bodies include through a variety of activities in agriculture, animal, pharmacueticals and personal care products and industry. The river is the final disposal for all the activities, water from Musi River becomes the primary material used various aspects of life. This study aims to determine the distribution pattern of antibiotics and content in the Musi River, Palembang. The study was conducted of March until October 2019, using analytic observational research by cross sectional measurements. Sampling points at three locations, location 1 (Ampera Bridge), location 2 (Kertapati Bridge) and location 3 (Musi 2 Bridge). Stages of Laboratory Analysis were carried out to determine the type of antibiotics contained in water samples using Agilent 6540 Liquid Chromatography / Quadrupole Time of Flight Mass Spectrometry (LC / Q-TOF / MS). LC / Q-TOF / MS produces good sensitivity and selectivity values and has the ability to screen untargetted drugs. Two types of antibiotics are identified, namely Ciprofloxacin and Netilmicin in all three water samples and quantitative analysis is needed to obtain the concentration.
\end{abstract}

Keywords: Water crisis, Musi River, Antibiotik

\begin{abstract}
ABSTRAK
Penggunaan antibiotik merupakan salah satu kebutuhan dasar kesehatan manusia yang berfungsi untuk menghambat atau membunuh pertumbuhan mikroorganisme. Sumber kegiatan yang berpotensi menghasilkan sisa antibiotik dalam badan air diantaranya melalui berbagai macam kegiatan dalam bidang pertanian, peternakan, produk farmasi dan perawatan tubuh dan industri. Sungai merupakan tempat pembuangan akhir dari semua sisa kegiatan, air dalam badan Sungai Musi di Kota Palembang menjadi bahan baku primer yang digunakan untuk memenuhi kebutuhan air dalam berbagai aspek kehidupan. Penelitian ini bertujuan untuk menentukan pola sebaran antibiotik dan kandungan antibiotik dalam badan air Sungai Musi Kota Palembang. Penelitian dilakukan dalam jangka waktu bulan Maret s.d. Oktober 2019, menggunakan penelitian observasi analitik dengan melakukan pengukuran cross sectional. Titik sampel di tiga lokasi, lokasi 1 (Jembatan Ampera), Lokasi 2 (Jembatan kertapati) dan lokasi 3 (Jembatan musi 2) merupakan badan Sungai Musi di Kota Palembang. Tahapan Analisis Laboratorium dilakukan untuk menentukan jenis antibiotik yang terdapat dalam sampel dengan menggunakan Agilent 6540 Liquid Chromatography/Quadrupole Time of Flight Mass Spectrometry (LC/Q-TOF/MS). LC/QTOF/MS menghasilkan nilai sensitivitas dan selektivitas yang baik serta memiliki kemampuan untuk melakukan screening terhadap obat-obatan yang belum diketahui jenisnya (untargetted).Teridentifikasi 2 jenis antibiotik yaitu Ciprofloxacin dan Netilmicin pada ketiga sampel air dan diperlukan analisis kuantitatif untuk mendapatkan konsentrasinya.
\end{abstract}

Kata Kunci: krisis air bersih, Sungai musi, antibiotik 


\section{PENDAHULUAN}

Data yang dikeluarkan oleh organisasi dunia WWF dalam laporannya Toxic Chemical mengungkapkan bahwa antara tahun 1930 sampai 2000, produksi bahan kimia yang diakibatkan oleh kegiatan manusia meningkat dari 1 juta menjadi 400 juta/tahun. Data statistik yang diterbitkan oleh Euro Stat pada 2013 mengungkapkan bahwa antara tahun 2002 dan 2011 lebih dari $50 \%$ total produksi bahan kimia menghasilkan senyawa berbahaya dan $70 \%$ diantaranya memiliki dampak terhadap lingkungan yang signifikan.

Permintaan terhadap air bersih di dunia terus meningkat (Gonzalez et al., 2012). Forum Air Dunia II (World Water Forum) di Den Haag pada Maret 2000 sudah memprediksi bahwa pelayanan air bersih bagi masyarakat masih sulit dilaksanakan dan Indonesia termasuk salah satu negara yang mengalami krisis air pada tahun 2025 (Tioritz, 2010). Ketersediaan air bersih di Indonesia masih terdapat banyak kendala terutama di daerah tepi sungai yang tercemar.

Sungai Musi dan Sungai Sekanak merupakan sungai yang berada di kawasan perkotaan yang sangat rentan dicemari oleh limbah industri dan limbah rumah tangga. Namun demikian, sebagian penduduk yang tinggal di kawasan kedua sungai ini masih memanfaatkan sungai tersebut terutama untuk anak-anak mandi. Sebagian penduduknya masih mengandalkan sungai tersebut untuk kepentingan mandi cuci kakus (MCK). Penelitian Kurniawan et al., (2017) menemukan kandungan dalam air limbah rumah sakit sebanyak 5 jenis antibiotik setelah melalui sistem pengolahan air limbah rumah sakit kota Palembang sehingga dalam jangka waktu tertentu akan mencapai wilayah perairan umum.

Air limbah yang berasal dari sarana pelayanan kesehatan seperti rumah sakit mengandung bahan kimia dan obatobatan yang bersifat karsinogenik dan genotoksik yang dapat menyebabkan penyakit kanker serta kelainan genetik (Orias dan Perrodin, 2013; Bayer et al., 2014; Sharma et al., 2015). Senyawa antibiotik yang berada di lingkungan dalam jangka waktu tertentu dan terusmenerus dapat menyebabkan beberapa mikroorganisme patogen menjadi persisten dan bertahan di lingkungan karena sulit diurai secara alami (Rahube dan Yost, 2010; Akter et al., 2012).

Micropollutants yang berada dalam lingkungan alam jumlah yang sangat kecil dengan konsentrasi bagian per miliar (ppb) atau bagian per triliun (ppt) dalam air minum memiliki dampak yang merugikan kesehatan manusia karena bersifat kronik (Ratola et al., 2012; Nam et al., 2014; Wibowo et al., Mariadi, et al., 2019). Potensi bahaya dari antibiotik yang berada di lingkungan perarian umum harus diantisipasi dengan melakukan screening sebagai langkah antisipasi awal dalam mengantisipasi pola sebaran antibiotik.

Santos et al. (2013) juga menemukan senyawa antibiotik seperti Ciprofloxacin,

Ofloxacin,

Sulfamethoxazole, Azithromycin, Clarithromycin, Acetaminophen dan Ibuprofen. Bailly, Levi dan Karolak (2013) menemukan senyawa antibiotik yang tergolong dalam golongan The Polar Organic Chemical Integrative Sampler (POCIS) compounds (Atenolol, Prednisolone, Methylprednisolone, Sulfamethoxazole, Ofloxacin, Ketoprofen). Mater et al., (2014) menemukan Ciprofloxacin, Tamoxifen dan Cyclophosphamide. Antibiotik Dexamethasone (Arsand et al., 2013), Carbamazepine (Nan dan Jin, 2012). Diclofenac, Amiodarone, Ritonavir, dan Clotrimazole (Escher et al., 2010); Amoxicillin, Ciprofloxacin, 
Fluoroquinolones, Arsenic, Mercury, Metracyclines, Sulfonamides dan Penicillin G (Varela et al., 2014).

Tujuan utama penelitian ini adalah menentukan jenis senyawa pencemar antibiotik yang terdapat dalam air sungai musi. Salah satu agen pencemar pada badan air karena memiliki sifat bahan yang berbahaya dan beracun, mengandung senyawa persisten adalah antibiotik. Antibiotik yang telah digunakan dalam jumlah yang besar, akan tetapi penelitian mengenai efek dan akibat dari penggunaannya di beberapa negara masih terbatas. Cemaran antibiotik akan masuk ke dalam badan air dan dampak yang sangat berbahaya adalah menyebabkan bakteri menjadi resisten. Pola sebaran dan jenis antibiotik pencemar dalam badan air harus dianalisis dan diantisipasi sehingga dapat menekan jenis bakteri resisten yang semakin berkembang di dunia.

\section{BAHAN DAN METODE}

\section{Jenis Penelitian}

Jenis penelitian bersifat observasi analitik dengan melakukan pengukuran cross-sectional, peneliti melakukan observasi atau pengukuran variabel pada saat tertentu. Subyek yang diamati hanya di obsevasi satu kali saja dan pengukuran variabel subyek dilakukan pada sampel pemeriksaan tersebut.

Antibiotik memiliki sifat resisten dan persisten apabila berada di lingkungan perairan walaupun dalam konsentrasi yang sangat kecil. Sifat antibiotik sebagai salah satu senyawa yang berbahaya dan beracun akan menimbulkan dampak turunan apabila secara terus-menerus dikonsumsi. Air bersih yang bebas dari antibiotik dan bakteri resisten menjadi permasalahan dunia harus ditanggulangi dan negara di Asia Tenggara belum memiliki regulasi mengenai hal ini.

\section{Laboratorium Pemeriksaan}

Pemeriksaan sampel dilakukan di laboratorium pemeriksaan yang memiliki kompetensi (akeditasi) dan instrumentasi yang digunakan tersedia. Laboratorium pemeriksaan yaitu PT. Angler Bio Chem Laboratory, Surabaya (Akreditasi KAN LP-514-IDN, SNI ISO/IEC 17025 :2008).

\section{Sampel dan Lokasi Penelitian}

Pengambilan sampel air Sungai Musi meliputi beberapa langkah yaitu, penggunaan alat pelindung diri, pengambilan grab dan komposit sampling, serta pengemasan sampel. Lokasi pengambilan sampel meliputi 3 lokasi dengan Sampel 1 (Jembatan Ampera), Sampel 2 (Jembatan Kertapati) dan Sampel 3 (Jembatan Musi 2), ketiga lokasi tersebut merupakan daerah yang padat penduduk dan lokasi terdekat dengan pusat kota. Sampel air sungai kemudian dikirim selanjutnya ke laboratorium pemeriksaan sampel disimpan ke dalam botol sampel polyetilen sebanyak 1 liter/titik dan kemudian dikirim ke laboratorium pemeriksaan. Wadah sampel air yang digunakan untuk menyimpan contoh harus memenuhi persyaratan yaitu terbuat dari bahan gelas atau plastik polietilen (PE) atau polipropilen (PP) atau teflon (Poli Tetra Fluoro Etilen, PTFE), dapat ditutup dengan kuat dan rapat, bersih dan bebas kontaminan, tidak mudah pecah dan tidak berinteraksi dengan sampel.

\section{Waktu Penelitian}

Penelitian akan dilakukan dalam dalam jangka waktu $\pm 0,5$ tahun dimulai pada bulan Maret 2019 .

\section{Instrumen Penelitian}

Sampel air sungai dikemas dengan baik sehingga aman untuk dikirim ke laboratorium pemeriksaan terakreditasi PT. Angler Bio Chem Laboratory di 
Surabaya. Metode pemeriksaan sampel air menggunakan Liquid Chromatography/Quadrupole Time of Flight Mass Spectrometry (LC/QTOF/MS) dapat menghasilkan nilai sensitivitas dan selektivitas yang baik serta memiliki kemampuan untuk melakukan screening terhadap obatobatan yang terdapat dalam sampel cairan yang belum diketahui jenisnya. Penggunaan Agilent 6540 QTOF/LC/MS merupakan suatu sistem instrumentasi yang terintegrasi dengan beberapa software pendukung yaitu Molecular Feature Extractor, Molecular Formula Generator dan Accurate Mass Databases untuk mendeteksi, mengidentifikasi dan memprediksi tingkat konsentrasi dari obat-obatan yang ada di dalam air.

Sampel diperiksa ke laboratorium yang terkareditasi. Air limbah yang diperiksa belum diketahui jenis-jenis antibiotik yang terdapat dalam sampel tersebut (untargetted). Proses screening dilakukan untuk memprediksi secara kualitatif jenis-jenis antibiotik yang terdapat dalam air limbah tersebut dengan menggunakan High Resolution Mass Spectrometry (LC/Q-TOF/MS) 6500 Series for the Detection of Pharmaceuticals in Water. Standard Operating Procedure (SOP) atau protokol kerja dalam menggunakan High Resolution Mass Spectrometry (LC/QTOF/MS) 6500 Series untuk pemeriksaan kualitatif air limbah rumah sakit sebagai berikut :

a. Analisis menggunakan column C18 dan Mobile Phase A (Methanol $10 \%$ with $5 \mathrm{mM}$ Ammonium acetate), Mobile Phase B (Methanol $10 \%$ with 5 $\mathrm{mM}$ Ammonium acetate)

b. Sampel air limbah dipersiapkan kemudian dilakukan evaporasi pada suhu 400C sampai kering (residu) c. Residu kemudian ditambahkan pelarut Methanol $50 \%$

d. Proses dengan menggunakan Vortek dan Ultrasonic

e. Centrifuge $10.000 \mathrm{rpm}$ selama 5 menit

f. Syringe dengan filter $0,22 \mu \mathrm{m}$

g. Injeksikan ke dalam alat High Resolution Mass Spectrometry (LC/Q-TOF/MS) 6500 Series.

\section{HASIL DAN PEMBAHASAN}

Deteksi kandungan pencemar air limbah yang mengandung micropollutans yang spesifik mengandung obat - obatan dapat dilakukan dengan menggunakan High Performance Liquid Chromatography (HPLC) (Dolar et al., 2013; Mendoza et al., 2015; Sabry et al., 2015). Menurut Ferrer dan Thurman (2012) penggunaan High Resolution Mass Spectrometry (LC/Q-TOF/MS) dengan prinsip spektrometer massa memungkinkan identifikasi dan karakterisasi lebih dari 100 obat-obatan dan metabolitnya dalam sumber air pada konsentrasi yang paling kecil dalam bagian per triliun (ppt). Metode pemeriksaan tersebut dapat memberikan sensitivitas dan selektivitas yang baik dalam mengidentifikasi jenis antibiotik yang belum diketahui golongannya (untargetted) dalam konsentrasi yang rendah pada sampel air.

Penggunaan Agilent 6540 QTOF/LC/MS merupakan suatu sistem instrumentasi yang terintegrasi dengan beberapa software pendukung yaitu Molecular Feature Extractor, Molecular Formula Generator dan Accurate Mass Databases untuk mendeteksi, mengidentifikasi dan memprediksi tingkat konsentrasi dari obat-obatan yang ada di dalam air.

Hasil analisis kualitatif menggunakan 3 sampel air sungai menggunakan instrument Liquid 
Chromatography/Quadrupole Time of Flight Mass Spectrometry (LC/QTOF/MS) Agilent 6540 Q-TOF/LC/MS mulai dari raw data sehingga menjadi kesimpulan akhir jenis antibiotik (Gambar 4.1 s.d 4.6) yang terdeteksi secara garis besar adalah sebagai berikut :

a) Molecular Feature Extractor (MFE) menghasilkan luaran pertama dari hasil pemeriksaan sampel air sungai dalam bentuk chromatogram dari senyawa antibiotik. b) Molecular Formula Generator (MFG) akan mengidentifikasi bentuk chromatogram tersebut untuk dicocokkan dengan rumus bangun senyawa tertentu sehingga dihasilkan spectrum antibiotik.

c) Accurate Mass Database (AMD) akan mencocokkan spectrum tersebut dengan berat molekul senyawa dan retention time yang ada di dalam library tools kemudian didapatkan jenis antibiotik yang terdeteksi (Tabel 4.1 s.d 4.3)

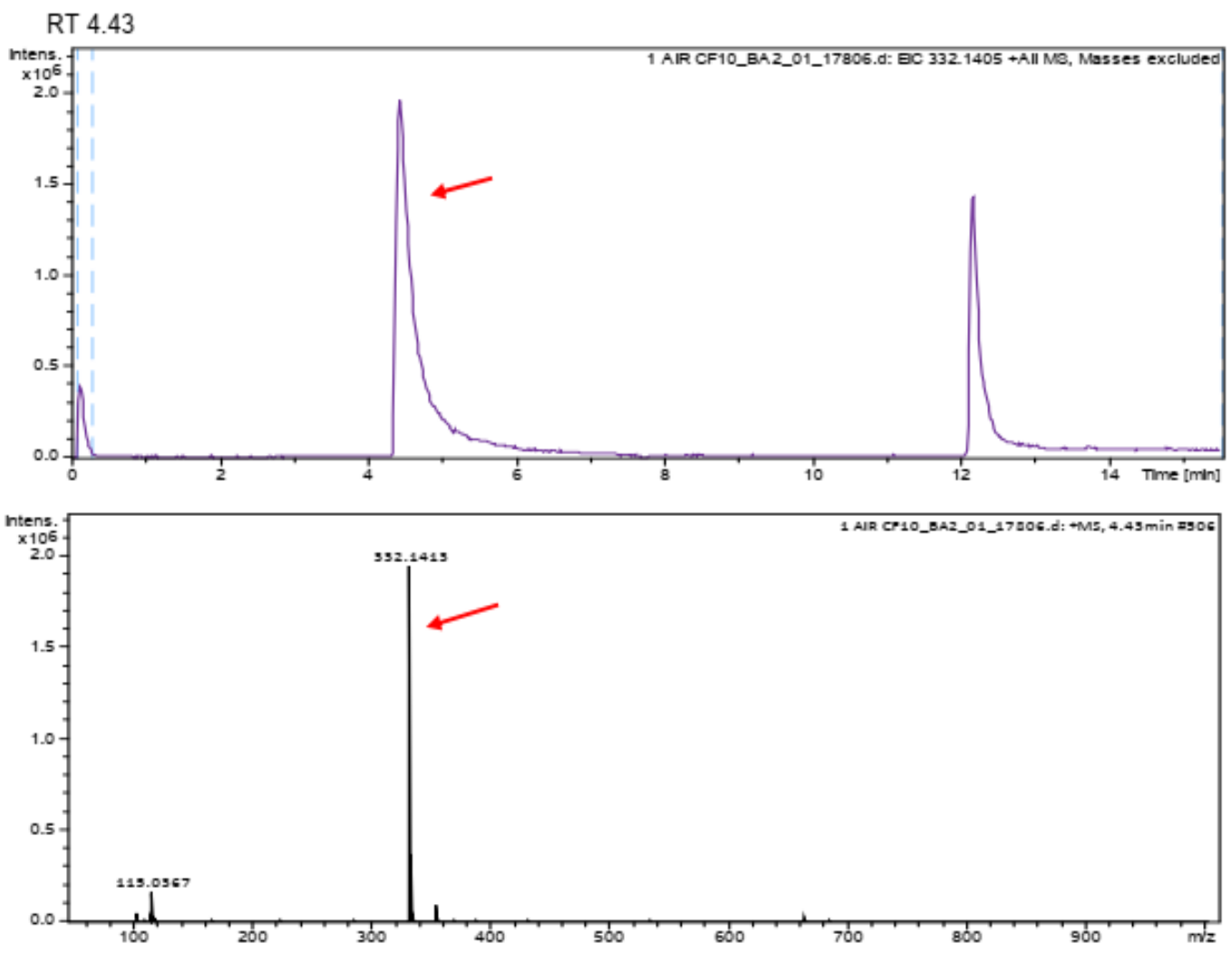

Gambar 4.1 Raw data Ciprofloxacin sampel 1 

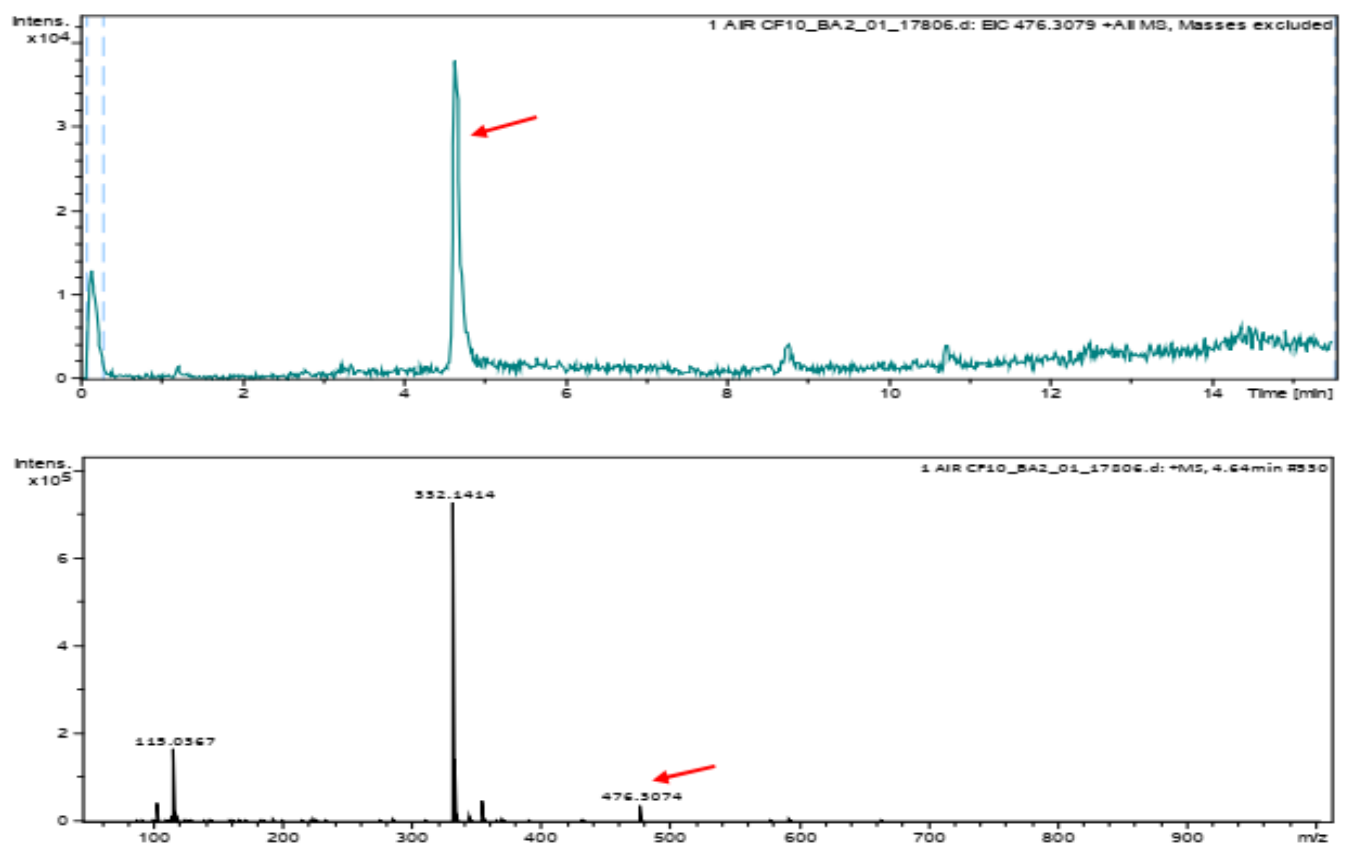

Gambar 4.2 Raw data Netilmicin sampel 1
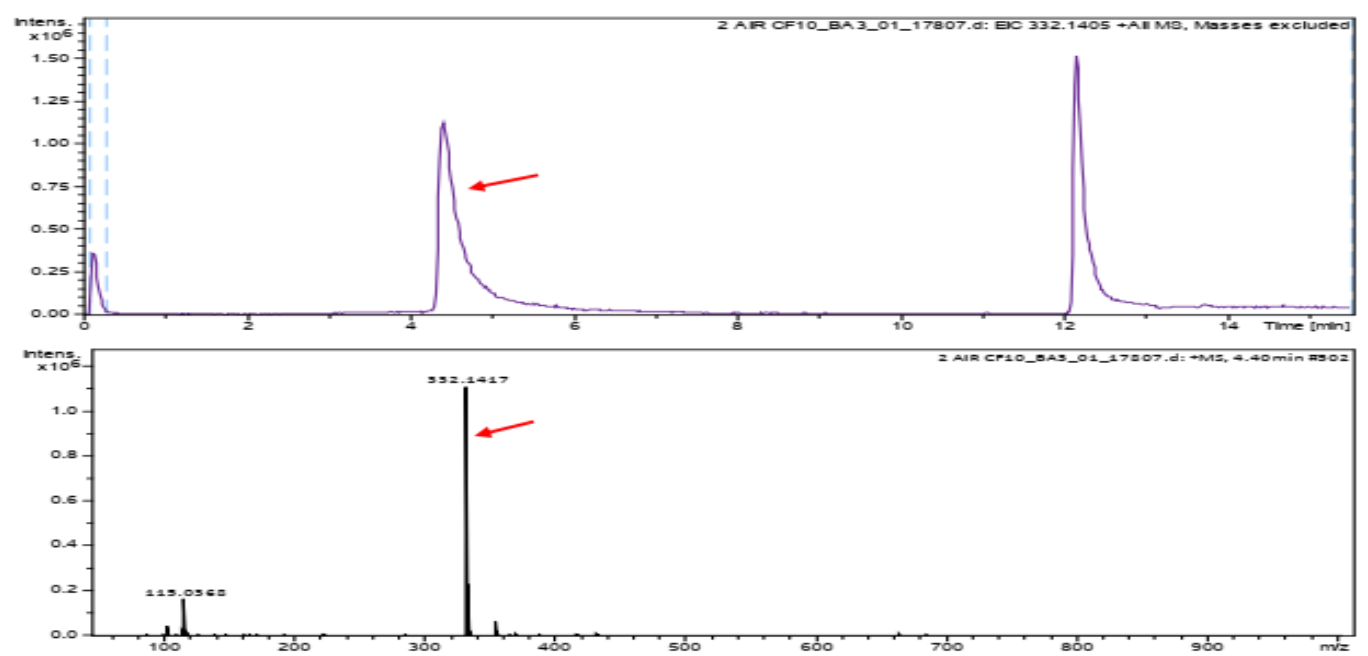

Gambar 4.3 Raw data Ciprofloxacin sampel 2 

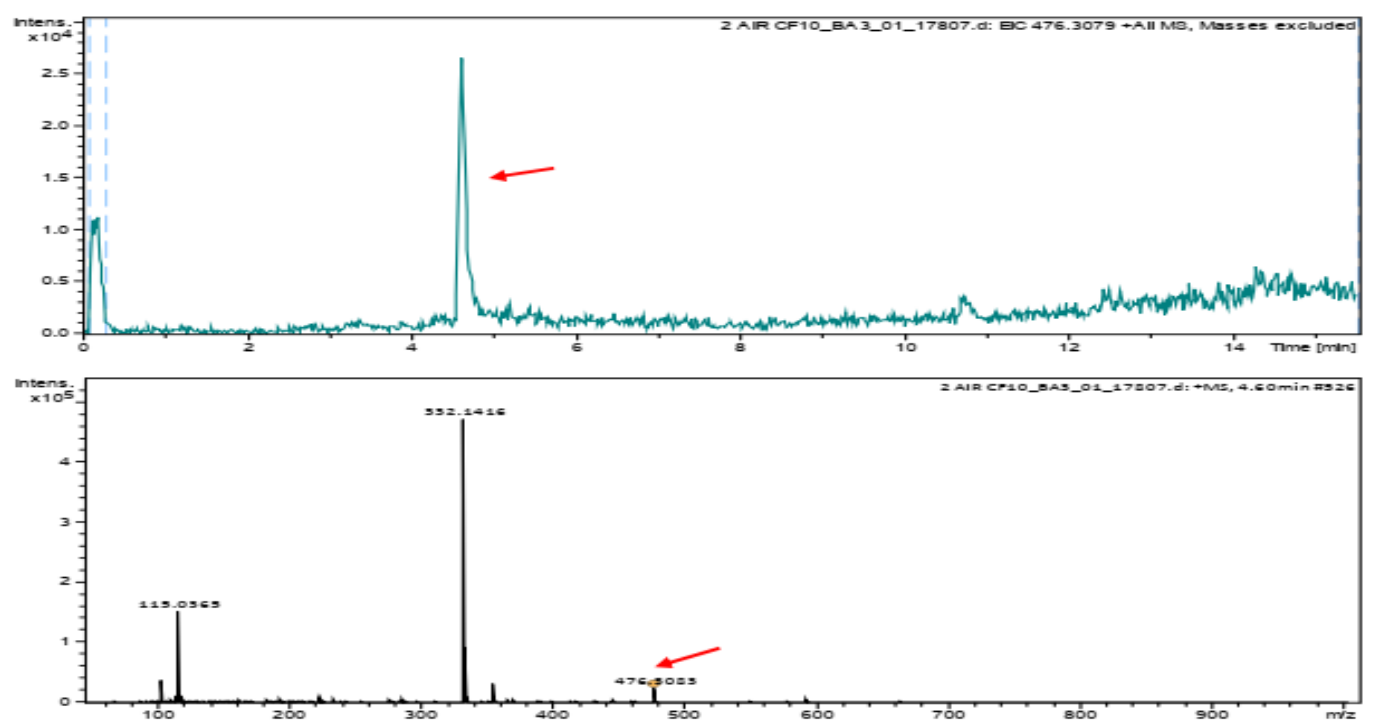

Gambar 4.4 Raw data Netilmicin sampel 2

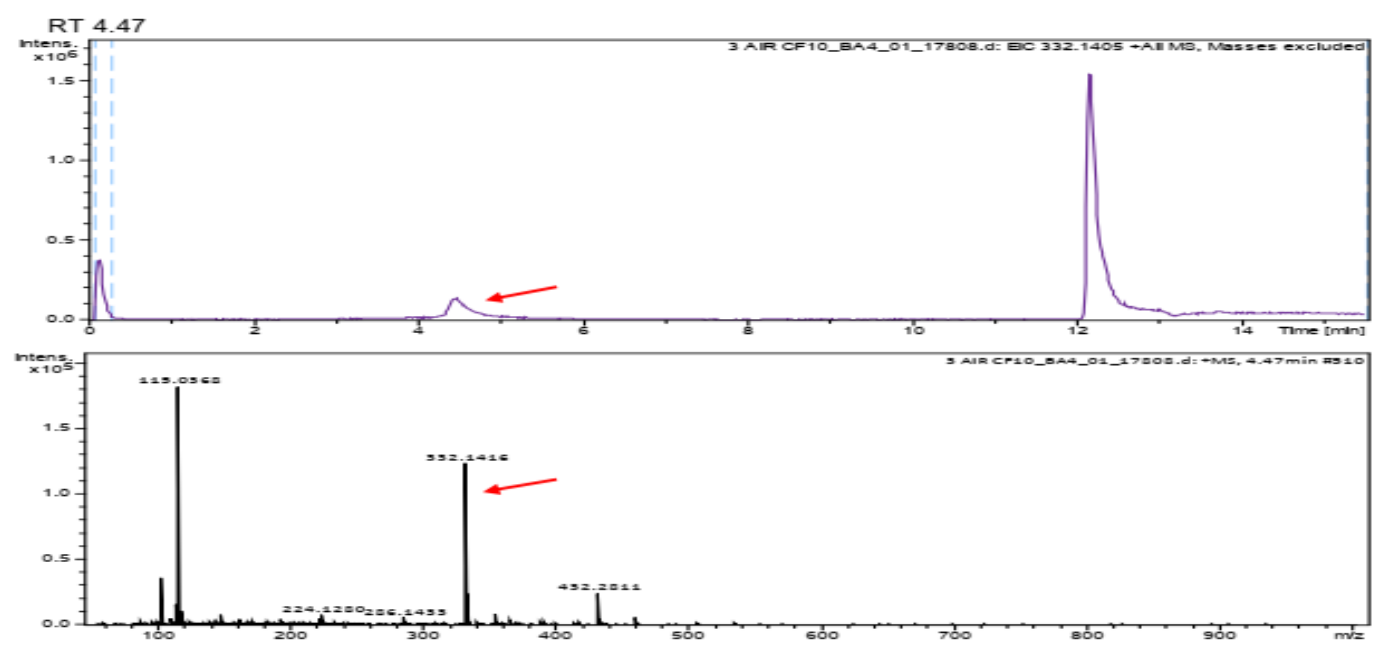

Gambar 4.5 Raw data Ciprofloxacin sampel 3 

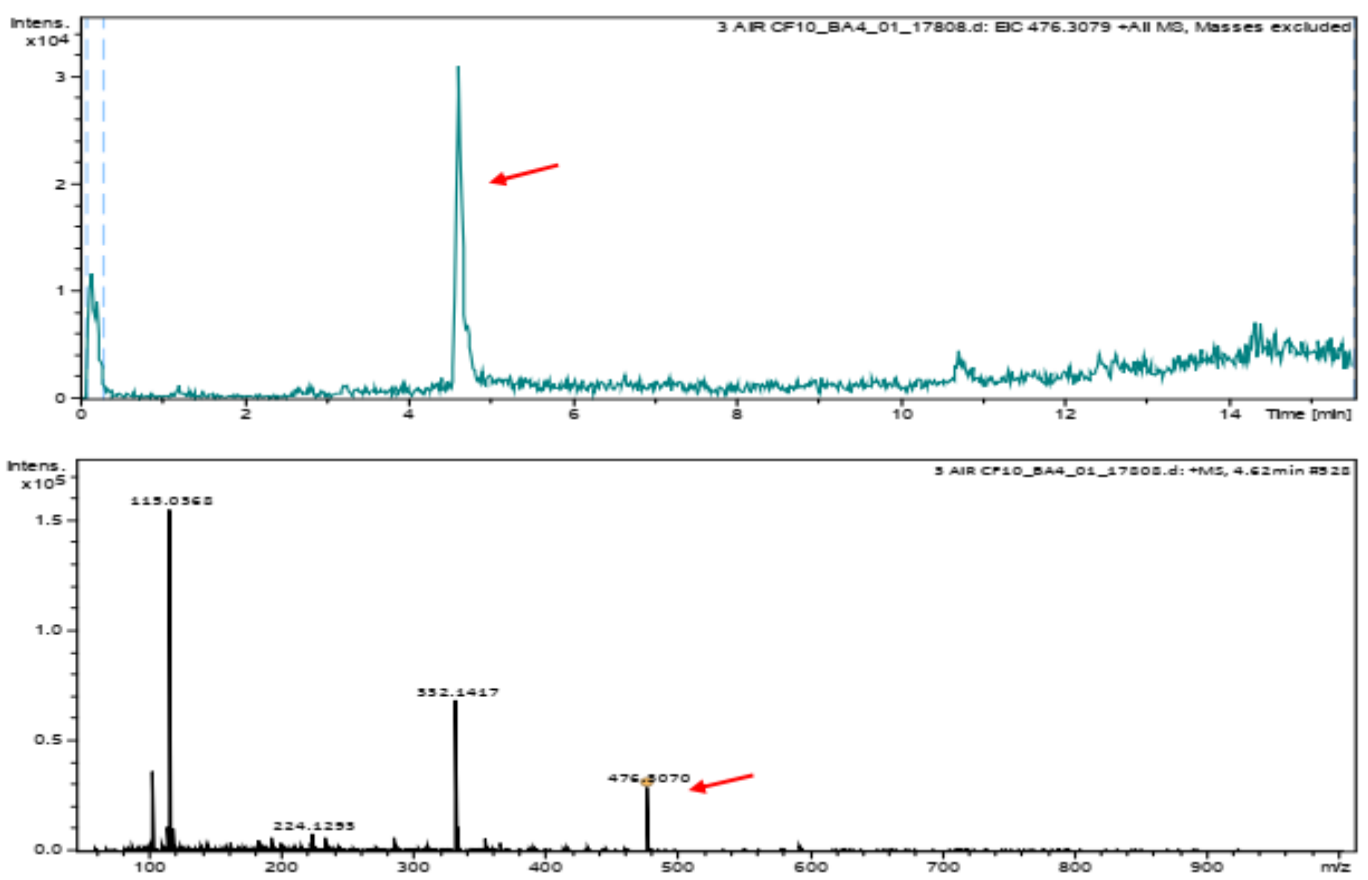

Gambar 4.6 Raw data Netilmicin sampel 3

Tabel 4.1 Hasil Analisis Sampel 1

\begin{tabular}{|l|c|c|c|c|c|c|c|}
\hline \multicolumn{1}{|c|}{ Detected Substances } & RT & Formula Mass & Mass (m/z) & err (mDa) & mSigma & $\begin{array}{c}\text { Peak } \\
\text { height }\end{array}$ & CF \\
\hline Ciprofloxacin & 4.43 & $\mathrm{C}_{17} \mathrm{H}_{18} \mathrm{FN}_{3} \mathrm{O}_{3}{ }^{1+}$ & 332.1413 & 1.2 & 4.60 & $1.30 \mathrm{E}+06$ & 10 \\
\hline Netilmicin & 4.64 & $\mathrm{C}_{21} \mathrm{H}_{41} \mathrm{~N}_{5} \mathrm{O}_{7}{ }^{1+}$ & 476.3074 & 0.5 & 18.80 & $4.00 \mathrm{E}+04$ & 10 \\
\hline
\end{tabular}

Tabel 4.2 Hasil Analisis Sampel 2

\begin{tabular}{|l||c|c|c|c|c|c|c|}
\hline \multicolumn{1}{|c|}{ Detected Substances } & RT & Formula Mass & Mass (m/z) & err (mDa) & mSigma & $\begin{array}{c}\text { Peak } \\
\text { height }\end{array}$ & CF \\
\hline \hline Ciprofloxacin & 4.43 & $\mathrm{C}_{17} \mathrm{H}_{18} \mathrm{FN}_{3} \mathrm{O}_{3}{ }^{1+}$ & 332.1417 & 0.80 & 5.80 & $2.00 \mathrm{E}+06$ & 10 \\
\hline Netilmicin & 4.60 & $\mathrm{C}_{21} \mathrm{H}_{41} \mathrm{~N}_{5} \mathrm{O}_{7}{ }^{1+}$ & 476.3083 & 0.50 & 11.30 & $4.00 \mathrm{E}+04$ & 10 \\
\hline
\end{tabular}

Tabel 4.3 Hasil Analisis Sampel 3

\begin{tabular}{|l||c|c|c|c|c|c|c|}
\hline \multicolumn{1}{|c||}{ Detected Substances } & RT & Formula Mass & Mass (m/z) & err (mDa) & mSigma & $\begin{array}{c}\text { Peak } \\
\text { height }\end{array}$ & CF \\
\hline \hline Ciprofloxacin & 4.47 & $\mathrm{C}_{17} \mathrm{H}_{18} \mathrm{FN}_{3} \mathrm{O}_{3}{ }^{1+}$ & 332.1416 & 1.10 & 4.80 & $1.50 \mathrm{E}+05$ & 10 \\
\hline Netilmicin & 4.64 & $\mathrm{C}_{21} \mathrm{H}_{41} \mathrm{~N}_{5} \mathrm{O}_{7}{ }^{1+}$ & 476.3083 & -0.90 & 18.60 & $3.00 \mathrm{E}+04$ & 10 \\
\hline
\end{tabular}

Riset yang dilakukan terhadap pada perairan umum dan ditemukan kandungan antibiotik Ciprofloxacin diantaranya :

a) Hamjinda et al. (2015) menggunakan lokasi penelitian di Kota Bangkok, Thailand menemukan Kuinolon, Ofloxacin, Levofloxacin,
Norfloksasin, Sulfametoksazol, Norfloksasin dan Ciprofloxacin

b) Mater et al. (2014) menemukan Ciprofloxacin, Tamoxifen dan Cyclophosphamide dengan lokasi penelitian di Perancis.

c) Varela et al. (2014) melakukan penelitian di Portugal dan 
menemukan

Amoxicillin, Ciprofloxacin, Fluoroquinolones, Arsenic, Mercury, Metracyclines, Sulfonamides dan Penicillin G.

d) Santos et al. (2013) menemukan senyawa antibiotik seperti Ciprofloxacin, Ofloxacin, Sulfamethoxazole, Azithromycin, Clarithromycin, Acetaminophen dan Ibuprofen dengan lokasi penelitian di Spanyol.

Identifikasi Ciprofloxacin dan Netilmicin yang terdeteksi pada air sungai musi dikarenakan tingkat penggunaan ciprofloxacin yang dapat secara bebas di gunakan dan diperoleh. Ciprofloxacin memiliki spektrum luas, aktif terhadap bakteri gram negatif maupun gram positif. Ciprofloxacin digunakan untuk pengobatan infeksi saluran pernafasan, saluran kemih, pencernaan, dan infeksi perut, termasuk infeksi oleh bakteri gram negatif (Escherichia coli, Haemophilus influenzae, Klebsiella pneumoniae, Legionella pneumophila, Moraxella catarrhalis, Proteus mirabilis, dan Pseudomonas aeruginosa), dan gram positif (Staphylococcus aureus, Streptococcus pneumoniae, Staphylococcus epidermidis, Enterococcus faecalis, dan Streptococcus pyogenes).

Hasil pemeriksaan laboratorium terhadap kandungan beberapa antibiotik dalam air limbah memperlihatkan Ciprofloxacin memiliki intensity tertinggi dibandinkan dengan Netilmicin. Intensity memperlihatkan perkiraan besaran konsentrasi Ciprofloxacin sebagai Senyawa antibiotik tertinggi dalam air. Data berikutnya mempertimbangkan nilai err (mDA) dan mSigma, Ciprofloxacin memiliki nilai yang paling kecil sehingga dapat disimpulkan tingkat sensitivitas dan selektivitas deteksi terhadap senyawa ini lebih baik. Ciprofloxacin dalam tingkat pemeriksaan dan analisis laboratorium memiliki tingkat kemudahan dengan aksessibilitas reagen ataupun standar.

$$
\text { Berdasarkan Certificate of }
$$

Analyzed (COA) Ciprofloxacin yang dikeluarkan oleh salah satu supplier di Indonesia, Dexa Medica bahwa salah satu karakteristik dari Ciprofloxacin yaitu larut dalam air walaupun dalam jumlah yang relatif sedikit. Sifat dari kelarutan tersebut akan menentukan banyaknya konsentrasi zat yang berada dalam air.

Legislasi di Asia khususnya Indonesia mengenai kandungan antibiotik dalam air belum mencantumkan parameter tersebut sedangkan legislasi yang berlaku di negara-negara Eropa melalui European Union Law (Eur-Lex) dalam Girardi et al. (2011) menyatakan bahwa kandungan antibiotik Ciprofloxacin di lingkungan yaitu perairan (ambang batas $\mathrm{EC}_{50} \leq 1 \mathrm{ppm}$ ) sangat beracun apabila terpapar ke organisme air dan di lingkungan tanah akan beracun apabila terpapar ke organisme tanah.

\section{KESIMPULAN}

Teridentifikasi 2 jenis antibiotik di perairan sungai musi yaitu terdeteksi Ciprofloxacin dan Netilmicin dengan intensitas tertinggi dimiliki oleh Ciprofloxacin. Perlu dilakukan analisis secara kunatitatif untuk menentukan konsentrasi dari zat antibiotik tersebut.

\section{UCAPAN TERIMA KASIH}

Penelitian ini disponsori oleh Direktorat Riset dan Pengabdian Masyarakat Direktorat Jenderal Penguatan Riset dan Pengembangan Kementerian Riset, Teknologi dan Pendidikan Tinggi dengan Nomor Kontrak 108/SP2H/LT/DRPM/2019 Tanggal 11 Maret 2019. PT.Angler BiochemLab Surabaya atas dukungan analisis laboratorium. Program Studi Doktor Ilmu Lingkungan Universitas Sriwijaya. 


\section{DAFTAR PUSTAKA}

Akter, F., Amin, M. R., Osman, K. T., Anwar, M. N., Karim, M. M., \& Hossain, M. A. (2012). Ciprofloxacin-resistant Escherichia coli in hospital wastewater of Bangladesh and prediction of its mechanism of resistance. World Journal Microbiol Biotechnol, 827834. http://doi.org/10.1007/s11274011-0875-3.

Arsand, D. R., Kümmerer, K., \& Martins, A. F. (2013). Removal of dexamethasone from aqueous solution and hospital wastewater by electrocoagulation. Science of the Total Environment, 351-357. http://doi.org/10.1016/j.scitotenv.20 12.10.100

Bailly, E., Levi, Y., Karolak, S., (2013). Calibration and field evaluation of polar organic chemical integrative sampler (POCIS) for monitoring pharmaceuticals in hospital wastewater. Environmental Pollution 174 (2013) 100e105. http://dx.doi.org/10.1016/j.envpol.2 012.10 .025

Bayer, A., Asner, R., Schüssler, W., Kopf, W., Weib, K., Sengl, M., \& Letzel, M. (2014). Behavior of sartans ( antihypertensive drugs ) in wastewater treatment plants, their occurrence and risk for the aquatic environment. Environ Sci Pollut Res. http://doi.org/10.1007/s11356014-3060-z.

Drlica, K. Perlin D.S. (2011). Antibiotic Resistance Understanding and Responding to an Emerging Crisis.Pearson Education, $\mathrm{N}$

Escher, B. I., Baumgartner, R., Koller, M., Treyer, K., Lienert, J., \&
Mcardell, C. S. (2010). Environmental toxicology and risk assessment of pharmaceuticals from hospital wastewater. Water Research, 45(1), 75-92. http://doi.org/10.1016/j.watres.2010 .08 .019

Eurostat.http://epp.eurostat.ec.europa.eu/t $\mathrm{gm} /$ table.do? tab $=$ table\&init $=1 \&$ plugi $\mathrm{n}=1 \&$ language $=$ en $\&$ pcode $=$ ten $000 \mathrm{e}$ w Jersey.

Girardi, C., Greve, J., Lamshöft, M., Fetzer, I., Miltner, A., Schäffer, A., \& Kästner, M. (2011). Biodegradation of ciprofloxacin in water and soil and its effects on the microbial communities. Journal of Hazardous Materials, 198, 22-30. https://doi.org/10.1016/j.jhazmat.201 1.10 .00

Gonzalez, P.A., Urtiaga, A.M., Ibanez, R., and Ortiz, I., (2012). State of Art and Review on The Treatment Technologies of Water Reverse Osmosis Concentrates. Elsevier Water Research. 46: 267-283.

Hamjinda, N. S., Chiemchaisri, W., Watanabe, T., \& Honda, R. (2015). Toxicological assessment of hospital wastewater in different treatment processes. Environmental Science and Pollution Research. http://doi.org/10.1007/s11356-0154812-0

Kurniawan, I., Nasir, S., Hermansyah, Mardiyanto, (2017). The Screening of Potential Antibiotics from Hospital Wastewater in Tropical Region (Case Study at Palembang, South Sumatra, Indonesia). Pollution Research Journal, Vol. 36, Issue 2, 2017; Page (343-351). ISSN 0257 8050 . 
Mater, N., Geret, F., Castillo, L., Faucetmarquis, V., Albasi, C., \& Pfohlleszkowicz, A. (2014). In vitro tests aiding ecological risk assessment of cipro floxacin, tamoxifen and cyclophosphamide in range of concentrations released in hospital wastewater and surface water. Environment International, 63, 191200.

http://doi.org/10.1016/j.envint.2013. 11.011

Mater, N., Geret, F., Castillo, L., Faucetmarquis, V., Albasi, C., \& Pfohlleszkowicz, A. (2014). In vitro tests aiding ecological risk assessment of cipro floxacin, tamoxifen and cyclophosphamide in range of concentrations released in hospital wastewater and surface water. Environment International, 63, 191200.http://doi.org/10.1016/j.envint.2 013.11 .011

Mariadi, P.D., Kurniawan, I., Setiawan, H., (2018). Lead and Cadmium Mobilization from Anas Moscha and Cairina Moschata Tissue Using PineappleExtract as Chealing Agents. Pollution Research Journal. 37 (2). 330-333. EM International.

Nam, S., Jo, B., Yoon, Y., \& Zoh, K. (2014). Occurrence and removal of selected micropollutants in a water treatment plant. Chemosphere, 95, 156-165.

http://doi.org/10.1016/j.chemosphere .2013 .08 .055

Nan, C. M., \& Jin, B. (2012). Photocatalytic treatment of high concentration carbamazepine in synthetic hospital wastewater. Journal of Hazardous Materials, 199200, 135-142. http://doi.org/10.1016/j.jhazmat.2011 .10 .067
Rahube, T. O., \& Yost, C. K. (2010). Antibiotic resistance plasmids in wastewater treatment plants and their possible dissemination into the environment. African Journal of Biotechnology, 9(54), 9183-9190.

Ratola, N., Cincinelli, A., Alves, A., \& Katsoyiannis, A. (2012). Occurrence of organic microcontaminants in the wastewater treatment process . A mini review. Journal of Hazardous Materials, 239-240, 1-18. http://doi.org/10.1016/j.jhazmat.2012 .05 .040

Santos, L. H. M. L. M., Gros, M., Rodriguez-Mozaz, S., DelerueMatos, C., Pena, A., Barceló, D., \& Montenegro, M. C. B. S. M. (2013). Contribution of hospital effluents to the load of pharmaceuticals in urban wastewaters: Identification of ecologically relevant pharmaceuticals. Science of The Total Environment, 461-462, 302316. http://doi.org/10.1016/j.scitotenv.201 3.04.077

Sharma, P., Mathur, N., Singh, A., \& Sogani, M. (2015). Monitoring hospital wastewaters for their probable genotoxicity and mutagenicity. Environment Monitoring Assessement. http://doi.org/10.1007/s10661-0144180-0

Tioritz, S. (2010). Kajian Solusi Krisis Air Bersih di Indonesia. Jurnal Teknik Elektro, Informatika, Mesin dan Sipil. Media Teknik. 4(1): 38-43

Varela, A. R., Nunes, O. C., Manaia, M., Rita, A., \& Andre, S. (2014). ScienceDirect Insights into the relationship between antimicrobial 
residues and bacterial populations in a hospital-urban wastewater treatment plant system. Water Research, 4. http://doi.org/10.1016/j.watres.2014. 02.003

Wibowo, Y., G., Maryani, A.T., Rosanti,

D., Rosarina, D. (2019). Microplastics in Marine Environment and Its Impact. Sainmatika: Jurnal Ilmiah Matematika dan Ilmu Pengetahuan Alam. Volume 16 No. 1, Juni 2019 DOI10.31851/sainmatika.v16i1.2884

WWF,ToxicChemical.http://wwf.panda.o rg/about_our_earth/teacher_resource s/webfieldtrips/toxics/ 